\title{
Disability and pain in capoeira practitioners
}

\author{
Jorge William de Sá Campos ${ }^{1,2,3}$ (D), Almir Vieira Dibai-Filho ${ }^{1,3}$ (D), Mayra Elaine Costa Cordeiro ${ }^{1,3}$ (), \\ Eder Rodrigo Mariano ${ }^{1,2}$ (D), Sérgio Augusto Rosa de Souza ${ }^{1,2 *}$
}

\begin{abstract}
SUMMARY
OBJECTIVE: This study aims to analyze the level of disability and pain in capoeira practitioners.

METHODS: This is a cross-sectional study. Data collection took place at the training sites of participants. The Self-Estimated Functional Inability because of Pain questionnaire for athletes (SEFIP-sport) was used to assess the pain and disability. Descriptive analysis was performed with the presentation of variables through mean and standard deviation (SD) or absolute number and percentage.

RESULTS: The sample consisted of 65 capoeira practitioners. Of these, 42 (64.61\%) reported pain or discomfort. The total score of the SEFIP-sport presented an average of 2.28 points ( $S D=2.65)$. The body regions with the highest reports of pain and disability were the knees, lower back, and wrist/hands. However, we observed a mild degree of disability measured by SEFIP-sport.

CONCLUSIONS: The knees, lower back, and wrists/hands were the regions of the body with the highest reports of pain and disability. However, the disability presented by capoeira practitioners was slight.

KEYWORDS: Martial arts. Musculoskeletal injury. Pain.
\end{abstract}

\section{INTRODUCTION}

Musculoskeletal injuries and pain are the possible adverse effects that can affect practitioners of various sports, from light activities, such as walking, to more intense sports, such as combat sports and fights ${ }^{1}$. Fights, in general, have high rates of sports injuries and are directly associated with the sports characteristics and gestures of each modality. Muscle contusion is the most frequent type of injury in medium-distance fights that use punches and kicks, and ligament injuries, dislocations, fractures, and muscle strains are mainly related to short-distance fights that use projections and twists ${ }^{2,3}$.

Capoeira is a Brazilian cultural manifestation that presents itself with different faces, such as fight, dance, art, sport, leisure, game, and folklore. It is characterized by being a game/fight of body dexterity practiced in pairs with the use of attacks such as punches, kicks, headbutts, elbows, dodges, and insinuations that focus on the partner, although there is not always contact. In addition, several turns are used, especially on the support of just one foot, just one arm or head, sudden changes in direction, throws, releases, and acrobatics, combined with attacks and dodges ${ }^{4}$.

Literature presents few studies on the characteristics of injuries in capoeira practitioners. From the previously implemented scientific initiatives, a case study points to the development of chronic subdural hematoma, supposedly due to translational, rotational, or angular movements of the head, as it creates an impulse load (acceleration or deceleration) on the surface of the brain, which can cause tension, compression, or shear effects 5 .

However, some studies show a significant percentage of injuries in capoeira practitioners, especially in the ankle, foot, and knee region ${ }^{1,6-9}$. In complement, Mariconda et al. ${ }^{10}$ observed that the hip region has great potential to be affected, and of the

\footnotetext{
'Universidade Federal do Maranhão, Departamento de Educação Física - São Luís (MA), Brazil.

¿Universidade Federal do Maranhão, Grupo de Estudo e Pesquisa em Luta, Artes Marciais e Esportes de Combate - São Luís (MA), Brazil.

${ }^{3}$ Universidade Federal do Maranhão, Grupo de Pesquisa em Reabilitação, Exercício e Movimento - São Luís (MA), Brazil.

*Corresponding author: sergio.souza@ufma.br

Conflicts of interest: the authors declare there is no conflicts of interest. Funding: none.

Received on August 29, 2021. Accepted on August 30, 2021.
} 
$17 \%$ of individuals reported hip pain, $91.7 \%$ had radiographic confirmation of femoroacetabular impingement.

In this context, despite the importance of previous studies observing the anatomical location of lesions in capoeira, functional factors were not properly reported. Thus, this study aimed to investigate the level of disability and pain in capoeira practitioners.

\section{METHODS}

\section{Study design and ethical aspects}

This is a cross-sectional study. Nonprobability sampling method was used. The study procedures were approved by the research ethics committee of the institution, in accordance with protocol number 3,641,542. All participants signed an informed consent form.

\section{Participants}

The inclusion criteria were age $\geq 14$ years, minimum practice time of 6 months, and should be a member of a Capoeira Group or Association in the city of Săo Luís (Maranhão, Brazil).

The exclusion criteria were the practice of another fighting, martial art, or combat sport modality besides capoeira; diagnosis of cognitive, neurological, degenerative, or rheumatologic disease; pregnancy; and the presence of amputations.

\section{Data collection}

Data collection took place at the training sites of participants. Initially, the collection of sociodemographic, personal, clini$\mathrm{cal}$, and related to the practice of the sport was carried out.

In addition, the Self-Estimated Functional Inability because of Pain questionnaire (SEFIP-sport) was applied. This is an adapted and validated questionnaire for the Brazilian population ${ }^{11,12}$, composed of 14 items, each relating to one body part, and it is possible to mark one of the five answers for each item, which correspond to scores from 0 to 4 (total score ranges between 0 and 56 points). The higher the score, the higher the disability.

\section{Data analysis}

We performed descriptive analysis with the presentation of variables through mean and standard deviation (SD) or absolute number and percentage. Data were processed in SPSS software, version 17.0 (Chicago, IL, USA).

\section{RESULTS}

A total of 69 capoeira practitioners were initially recruited, and four were excluded, two of them for practicing another fighting, martial art or combat sport modality; one for not having minimum practice time; and one for not answering all the items in the questionnaire, totaling a final sample of 65 participants, aged between 14 and 53 years (mean $=25.71$ years, $S D=11.03$ ), $40(61.54 \%)$ males and $25(38.46 \%)$ females. The average time of practice of the fighting modality was 10.13 years $(\mathrm{SD}=9.55)$, ranging from 1 to 36 years.

Of the 65 capoeira practitioners, 42 (64.61\%) reported pain or discomfort. The total score of the SEFIP-sport presented an average of 2.28 points $(S D=2.65)$. According to Table 1 with the SEFIP-sport analysis, we observed that the most affected body regions with pain were the knees, lower back, and wrists/ hands. Similarly, the body regions with the highest mean disability scores (ranging from 0 to 4 ) were the knees, lower back, and wrist/hands. However, we observed a mild degree of disability measured in the SEFIP-sport by the body part, with a score ranging from $0.05(1.25 \%)$ to $0.40(10 \%)$.

\section{DISCUSSION}

This study is a pioneer in reporting pain and disability in capoeira practitioners. Of the 65 participants, 42 (64.61\%) reported musculoskeletal pain or discomfort. We observed that the body regions with the greatest pain and disability were the knees, lower back, and wrist/hands. However, the pain and disability observed in the sample were mild ( $\leq 10 \%$ of the maximum score per item of the SEFIP-sport).

Table 1. Report of pain and disability of capoeira practitioners $(n=65)$.

\begin{tabular}{l|c|c}
\multirow{2}{*}{ Body parts } & $\begin{array}{c}\text { Pain or } \\
\text { discomfort report }\end{array}$ & $\begin{array}{c}\text { SEFIP-sport } \\
\text { score (0-4) }\end{array}$ \\
\cline { 2 - 3 } Neck & $\mathrm{n}(\%)$ & Mean (SD) \\
\hline Shoulders & $5(7.69)$ & $0.08(0.27)$ \\
\hline Elbows & $3(12.30)$ & $0.17(0.49)$ \\
\hline Wrists/hands & $11(16.91)$ & $0.05(0.21)$ \\
\hline Upper back & $9(13.84)$ & $0.22(0.54)$ \\
\hline Lower back & $13(20.00)$ & $0.15(0.40)$ \\
\hline Hips & $8(12.30)$ & $0.23(0.49)$ \\
\hline Thighs (front) & $9(13.84)$ & $0.17(0.52)$ \\
\hline Thighs (back) & $6(9.23)$ & $0.20(0.56)$ \\
\hline Knees & $14(21.54)$ & $0.14(0.50)$ \\
\hline Legs (front) & $3(4.61)$ & $0.40(0.90)$ \\
\hline Calves & $3(4.61)$ & $0.06(0.30)$ \\
\hline Ankles & $10(15.37)$ & $0.15(0.36)$ \\
\hline Feet & $11(16.92)$ & $0.20(0.47)$
\end{tabular}


Considering the knee, the pain can be directly linked to the overload imposed on this joint by the sudden change of direction, hyperextension caused by the execution of kicks and dodges, jumps, and landings common in the practice of capoeira that can accentuate the frictional forces and make this region more susceptible to injury and pain $^{13}$. In the study conducted by Zucca and Grüninger', $56.1 \%$ of the volunteers had injuries in the knee region and the authors listed acrobatics as the most harmful movements in the practice of capoeira, being responsible for $49.1 \%$ of the injuries.

It is necessary to draw attention to the fact that the lower back has the second highest percentage in relation to disability in our study. The study conducted by Moraes et al. ${ }^{14}$ with 45 capoeira practitioners of both sexes pointed out the presence of pain and/or lumbar discomfort in $36.6 \%$ of the individuals. This fact may be directly related to preexisting or undiagnosed injuries. In addition, some blows and acrobatics present in capoeira, such as mortals, screws, falls, and flourishes, can cause compressive force in the lower back due to the impact on the ground ${ }^{14}$. Furthermore, overuse is pointed out by Sanchez et al. ${ }^{15}$ as the mechanism responsible for most of the injuries reported during the practice of capoeira.

The wrists and hands play a very important role during the capoeira game, as many punches and dodges are performed with at least one hand on the ground. At other times, the body of practitioner is fully supported by the hands and suffers from the frequent falls inherent in the sports practice. Bonfim and Gomes ${ }^{16}$ showed that $66 \%$ of practitioners who participated in the study reported pain in the wrists/hands and $65.22 \%$ of respondents did not stop the training, even if they were feeling pain or injured.
However, despite the reduced value of disability, attention to complaints of pain and discomfort on the part of practitioners should always be considered by health professionals, as even low-intensity pain may indicate possible musculoskeletal injuries ${ }^{17}$. Therefore, clinical professionals and trainers should turn their attention to the regions most affected by pain and disability in capoeira practitioners. We hypothesize that preventive measures focused on the joint, muscle, and gestures of the fighting modality can be beneficial to capoeira practitioners. However, clinical trials must be conducted to confirm this hypothesis.

\section{CONCLUSIONS}

Of the capoeira practitioners in our sample, $64.61 \%$ reported musculoskeletal pain or discomfort. The knees, lower back, and wrists/hands were the parts of the body with the highest reports of disability. However, the disability presented by capoeira practitioners was slight.

\section{AUTHORS" CONTRIBUTIONS}

JWSC: Conceptualization, Data curation, Formal analysis, Methodology, Writing - original draft. AVDF: Conceptualization, Data curation, Formal analysis, Methodology, Writing review \& editing. MECC: Conceptualization, Data curation, Formal analysis, Methodology, Writing - original draft. ERM: Conceptualization, Data curation, Formal analysis, Methodology, Writing - original draft. SARS: Conceptualization, Data curation, Formal analysis, Methodology, Project administration, Writing - review \& editing.

\section{REFERENCES}

1. Saragiotto BT, Pripas F, Almeida MO, Yamato TP. Prevalência de dor musculoesquelética em praticantes de caminhada: um estudo transversal. Fisioter Pesqui. 2015;22(1):29-33. https:// doi.org/10.590/1809-2950/13036422012015

2. Hammami N, Hattabi S, Salhi A, Rezgui T, Oueslati M, Bouassida A. Combat sport injuries profile: a review. Sci Sports. 2018;33(2):73-9. https://doi.org/10.1016/j. scispo.2017.04.014

3. Leme FSP. Epidemiologia das lesões nas artes marciais: revisão narrativa. [Conclusão de curso]. Belo Horizonte: Universidade Federal de Minas Gerais; 2016.

4. Fontoura ARR, Guimarães ACA. History of Capoeira. Journal of Physical Education. 2002;13(2):141-50.

5. Türkoğlu E, Serbes G, Sanli M, Sari O, Sekerci Z. Chronic subdural hematoma in capoeira sport. Turk Neurosurg. 2008;18(1):39-41. PMID: 18382976
6. Gomes Neto M, Rosário M, Arcanjo FL, Conceição CS. Estudo comparativo de lesões musculoesqueléticas em diferentes modalidades de capoeira. Revista Terapia Manual. 2012;10(50):359-63.

7. Freire RV, Costa VV, Vasconcelos Filho FSL, Escudeiro SS, Machado AAN. Prevalência de lesões em praticantes de capoeira da cidade de Fortaleza/CE. Revista Brasileira de Prescrição e Fisiologia do Exercício. 2015;9(55):526-35.

8. Andrade RS. Caracterização de lesões em praticantes de capoeira do Distrito Federal. [dissertação]. Brasília: Faculdade de Ceilândia, Universidade de Brasília; 2016.

9. Zucca LCZ, Grüninger BLS. Incidência de lesões musculoesqueléticas em praticantes de capoeira. Revista Intersaúde. 2020;1(2):101-17.

10. Mariconda M, Cozzolino A, Di Pietto F, Ribas M, Bellotti V, Soldati A. Radiographic findings of femoroacetabular impingement in capoeira players. Knee Surg Sport Traumatol Arthrosc. 2014;22(4):874-81. https://doi.org/10.1007/s00167-014-2850-7 
11. Reis-Júnior JR, Protázio JB, Muribeca-de-Castro AM, Pinheiro JS, Takahasi HY, Pires FO. Brazilian version of the self-estimated functional inability because of pain questionnaire for musculoskeletal injuries relating to dance and sport: translation and cross-cultural adaptation. Sao Paulo Med J. 2020;138(1):11-8. https://doi.org/10.1590/15163180.2019.0375.R1.08102019

12. Reis-Júnior JR, Pinheiro JS, Protázio JB, Pinheiro CAB, Fidelisde-Paula-Gomes CA, Pires FO, et al. Self-estimated functional inability because of pain questionnaire for athletes: a reliability and construct validity study. J Chiropr Med. 2021;20(1):23-9. https://doi.org/10.1016/j.jcm.2021.02.002

13. Sena CRPA, Carvalho ALM. Lesões de joelho na prática da capoeira. Recanto das Letras [serial on line] 2012 Oct [cited on August 2, 2021]. Available from: https://www.recantodasletras. com.br/artigos-de-esporte/3957910.
14. Moraes ERP, Silva MAG, Santos JP. A prevalência de lombalgia em capoeiristas do Rio de Janeiro. Fisioterapia Brasil. 2003;4(5):311-19.

15. Sanchez DCB, Luiz CCS, Silva PC, Casa Junior AJ. Prevalência de morbidades musculoesqueléticas referidas em praticantes de capoeira. In: Anais do II Congresso Brasileiro e I Congresso Internacional da Associação Brasileira de Fisioterapia TraumatoOrtopédica. 2017;2(1). Available from: http://seer.uftm.edu. br/anaisuftm/index.php/abrafito/article/view/2049

16. Bonfim GCS, Gomes MF. A ocorrência de lesões em praticantes de capoeira no município de Fortaleza. Revista Diálogos Acadêmicos. 2013;2(1):33-40.

17. Ramel E, Moritz $U$, Jarnlo GB. Validation of a pain questionnaire (SEFIP) for dancers with a specially created test battery. Medical Problems of Performing Artistis. 1999;14(4):196-203. 